\title{
The Effects of Polymorphisms of Death Pathway Genes and Mitochondrial Pathway Genes in Intervertebral Disc Degeneration
}

\author{
Betul ESER ${ }^{1}$, Olcay ESER ${ }^{2}$, Esra ASLAN ${ }^{3}$, Habibullah DOLGUN ${ }^{4}$ \\ 'Balıkesir University, Faculty of Medicine, Department of Medical Genetics, Balıkesir, Turkey \\ ${ }^{2}$ Balıkesir University, Faculty of Medicine, Department of Neurosurgery, Balıkesir, Turkey \\ ${ }^{3}$ Afyon Kocatepe University, Faculty of Medicine, Department of Histology and Embryology, Afyonkarahisar, Turkey \\ ${ }^{4}$ Diskapi Yildirim Beyazit Training and Research Hospital, Department of Neurosurgery, Ankara, Turkey
}

\section{ABSTRACT}

\begin{abstract}
AIM: It has been proposed that apoptosis is effective on intervertebral disc degeneration. This study is the first study in which both polymorphisms and expressions of apoptotic genes in patients with intervertebral disc degeneration (IVDD) are evaluated together. The aim of our study is to determine whether polymorphisms and expressions of apoptotic genes involved in both pathways are related with grades of IVDD or not.
\end{abstract}

MATERIAL and METHODS: Blood and tissue samples of 100 patients diagnosed with lumbar disc degeneration were collected. Patients were divided into 2 groups according to their radiological degeneration grades; grade 2 (mild), and grade 3 and 4 (severe). Polymorphisms in Fas (rs 2234767), Bcl-2 (rs 1801018) and Bax (rs 4645878) genes were determined with real-time PCR. Expressions of these genes were analyzed immunohistochemically following histological degeneration scoring.

RESULTS: Whereas no relationship was found among polymorphisms of Fas and Bax genes and their expressions, we have determined a relationship among GG genotype of Bcl-2 and their expressions. Additionally, the ratio of Bax-positive cells was related with IVDD grades. Moreover, radiological degeneration grades were compatible with histological degeneration scores.

CONCLUSION: GG genotype of Bcl-2 gene may influence the level of its expression and may be effective on the development of IVDD. Additionally, expression of Bax gene may be related with different grades of IVDD.

KEYWORDS: Apoptosis, Expression, Intervertebral disc degeneration, Polymorphism

\section{INTRODUCTION}

I ntervertebral disc degeneration (IVDD) is a pathology that is frequently seen in adults and causes morbidity. Although its etiology is not well known, it is known that histological changes in the anatomical regions of the intervertebral disc (IVD) cause cell death and degradation of the extracellular matrix (ECM) (3). It has been suggested that apoptosis, especially in disc cells, promotes degenerative process by causing cellular loss $(1,5)$.
Various molecules and pathways that regulate cellular apoptosis have been reported. One of these is death receptor pathway and another one is the mitochondrial pathway. The Fas/ Fas Ligand (FasL) complex participates in the death receptor pathway. Fas, which is a cell surface receptor, triggers cell death signal through binding to FasL. In herniated human disc tissue, increased expression of Fas and FasL has been demonstrated $(15,16)$. The mitochondrial pathway is triggered by up-regulation of wild-type p53 and is carried on by regulation 
of Bcl-2 and Bax (9). As a result of the blockade of the antiapoptotic effect of $\mathrm{Bcl}-2$ and impairment of the equilibrium between Bcl-2 and Bax, the permeability of the mitochondrial membrane increases and the organ swells and ruptures. These two pathways participating in process of apoptosis bind to each other with a pro-apoptotic protein called Bid (14). It is thought that the Bid protein functions by either inhibiting anti-apoptotic proteins such as Bcl-2 or activating pro-apoptotic proteins such as Bax (23).

After detection of excessive cellular loss especially in the nucleus pulposus during the process of IVDD, studies have concentrated on the genes of apoptosis. It has been decided that a relationship among IVD cells that decrease as a result of excessive programmed cell death and degradation of extracellular matrix $(1,15,16)$. However, in IVDD, in which genetics have been supposed to participate in the etiology, no study that investigated whether polymorphisms of the genes of apoptosis have an effect on the expression of these genes was encountered.

In this study, we aimed to determine whether polymorphisms of death pathway genes (Fas) and mitochondrial pathway genes (Bcl-2 and Bax) influence expressions of $\mathrm{Fas}, \mathrm{Bcl}-2$ and Bax in human IVD tissue.

\section{MATERIAL and METHODS}

\section{Subjects}

One hundred patients, (mean age 49.03 \pm 12.52 years) diagnosed as lumbar IVDD with magnetic resonance imaging (MRI), were involved in this study. While the study group was being organized, external factors that may cause disc degeneration such as heavy lifting, using vibrating vehicles, and smoking were excluded. Grading of disc degeneration was made according to Schneiderman's classification (18): Grade 1 (normal) normal signal intensity, Grade 2 (intermediate) heterogeneously reduced signal intensity, Grade 3 (marked) diffuse signal loss, Grade 4 (absent) absence of signal. For Grade 1 patients, non-operative medical treatment was planned. Patients who were decided to be operated were grouped as Grade 2 (mild form) and Grade 3-4 (severe form). Prior to the operation, information was given to the patients and informed consent that was approved by ethics committee of the university were signed by the patients. During lumbar discectomy, blood and tissue samples were collected from the patients. Tissue samples were fixated with $10 \%$ formalin and buried in paraffin blocks for histological and immunohistochemical analysis. Deoxyribonucleic acid (DNA) extraction was performed from the blood samples collected in hemogram tubes.

\section{Genetic Analysis}

Genomic DNA of each patient was extracted using GeneJet DNA Purification Kit (Thermo Scientific Labvision Corp, Fremont, CA, USA). From all DNAs, polymorphisms of Fas gene (rs 2234767), Bcl-2 gene (rs 1801018) and Bax gene (rs4645878) were determined using, FastStart DNA MasterPLUS HybProbe (Roche Diagnostics, Germany) in
LightCycler ${ }^{\circledR}$ Nano device and specific primaries according to following parameters: $95^{\circ} \mathrm{C}$ for 10 minutes, followed by 45 cycles with at $95^{\circ} \mathrm{C}$ for 10 seconds and at $60^{\circ} \mathrm{C}$ for 10 seconds and at $72^{\circ} \mathrm{C}$ for 15 seconds.

\section{Histopathological Examination}

Tissue preparation: For histopathological examinations, the tissues were fixed in $10 \%$ neutral formalin. Routine tissue processing was subjected to samples. Then the samples were embedded in paraffin and $5 \mu \mathrm{m}$ sections were taken to classic and poly-lysine-coated slides.

Hematoxylin-Eosin and Alcian Blue-PAS staining: Sections were deparaffinized and rehydrated and then HematoxylinEosin (H\&E) and Aniline Blue-PAS stainings were performed for determining Histological Degeneration Score (HDS) described by Boos et al. (4). All the samples were evaluated under light microscope (Eclipse E-600, Nikon, Japan) using an image analysis system (NIS Elements Nikon, Japan).

The grading system is based on four parameters as follows;

1. Cell density (chondrocyte proliferation)

2. Structural alterations (tears and clefts)

3. Granular changes

\section{Mucous degeneration}

All the criteria were described at Table I. While H\&E staining was used for evaluation of cell density, structural alterations and granular changes (Figure 1A-C), Aniline Blue-PAS staining was used for the evaluation of mucoid degeneration (Figure 1D).

\section{Immunohistochemistry for Fas, Bcl-2 and Bax}

Sections were taken onto poly-lysine-coated slides and then the slides were labeled with Fas (Figure 2A,B), Bcl-2 (Figure $2 \mathrm{C}, \mathrm{D}$ ), and $\mathrm{Bax}$ (Figure 2E,F) primary antibodies for the immunohistochemically evaluation. Citrate buffer $(\mathrm{pH}=6.0)$ was used for antigen retrieval in microwave. 3\% hydrogen peroxide was used for blocking endogenous peroxidase activity for 12 minutes. Bax primary antibody (BioGenex PU347-UP, 1/50 dilution), Bcl-2 primary antibody (BioGenex NU 541-UC,1/50 dilution) and Fas primary antibody (Thermo Scientific, PA-1 37368, 1/50 dilution) were dropped all the slides and incubated overnight at $+4^{\circ} \mathrm{C}$. After incubation, horseradish peroxidase (HRP) secondary antibody kit (Antipolyvalent HRP, Labvision Corp, Fremont, CA, USA) was used as a secondary antibody and sections were visualized with AEC kit (Labvision Corp, Fremont, CA, USA). Finally, all slides were counterstained with Mayer's Hematoxylin and mounted with water-based mounting medium. All preparations were evaluated by two different histology specialists who did not know clinical and radiological data.

In each sample, 100 cells were counted in different areas and the number of immunopositive cells and then the ratio of immunopositive cells/all the counted cells were calculated. All the data were statistically analyzed. 
Table I: Modified Parameters of Disc Degeneration (4)

\begin{tabular}{|c|c|}
\hline Criteria & Grading \\
\hline $\begin{array}{l}\text { Cell density (Chondrocyte proliferation) } \\
\text { Multiple chondrocytes growing in small rounded groups or } \\
\text { clusters sharply demarcated by a rim of territorial matrix }\end{array}$ & $\begin{array}{l}0=\text { no proliferation } \\
1=\text { increased cell density } \\
2=\text { connection of two chondrocytes } \\
3=\text { small size clones (several chondrocytes grouped } \\
\text { together, } 3-7 \text { cells) } \\
4=\text { moderate size clones }(8-15 \text { cells) } \\
5=\text { huge clones }(>15 \text { cells) }\end{array}$ \\
\hline $\begin{array}{l}\text { Structural alterations (tears and clefts) } \\
\text { Concentric tears following the collagen fiber bundle } \\
\text { orientation in the annulus fibrosus or radiating defects } \\
\text { extending from nucleus pulposus to the outer annulus } \\
\text { lamellae parallel or oblique to the end plate (clefts) }\end{array}$ & $\begin{array}{l}0=\text { absent } \\
1=\text { rarely present } \\
2=\text { present in intermediate amounts between } 1 \text { and } 3 \\
3=\text { abundantly present } \\
4=\text { scar/tissue defects }\end{array}$ \\
\hline $\begin{array}{l}\text { Granular changes } \\
\text { Eosinophilic staining amorphous granules within the } \\
\text { fibrocartilage matrix }\end{array}$ & $\begin{array}{l}0=\text { absent } \\
1=\text { rarely present } \\
2=\text { present in intermediate amounts between } 1 \text { and } 3 \\
3=\text { abundantly present }\end{array}$ \\
\hline $\begin{array}{l}\text { Mucous degeneration } \\
\text { Cystic, oval or irregular areas with intense deposition of } \\
\text { acid mucopolysaccharides staining dark blue with Alcian } \\
\text { Blue PAS }\end{array}$ & $\begin{array}{l}0=\text { absent } \\
1=\text { rarely present } \\
2=\text { present in intermediate amounts between } 1 \text { and } 3 \\
3=\text { abundantly present }\end{array}$ \\
\hline
\end{tabular}

Histologic Degeneration Score (HDS) 0-15 points

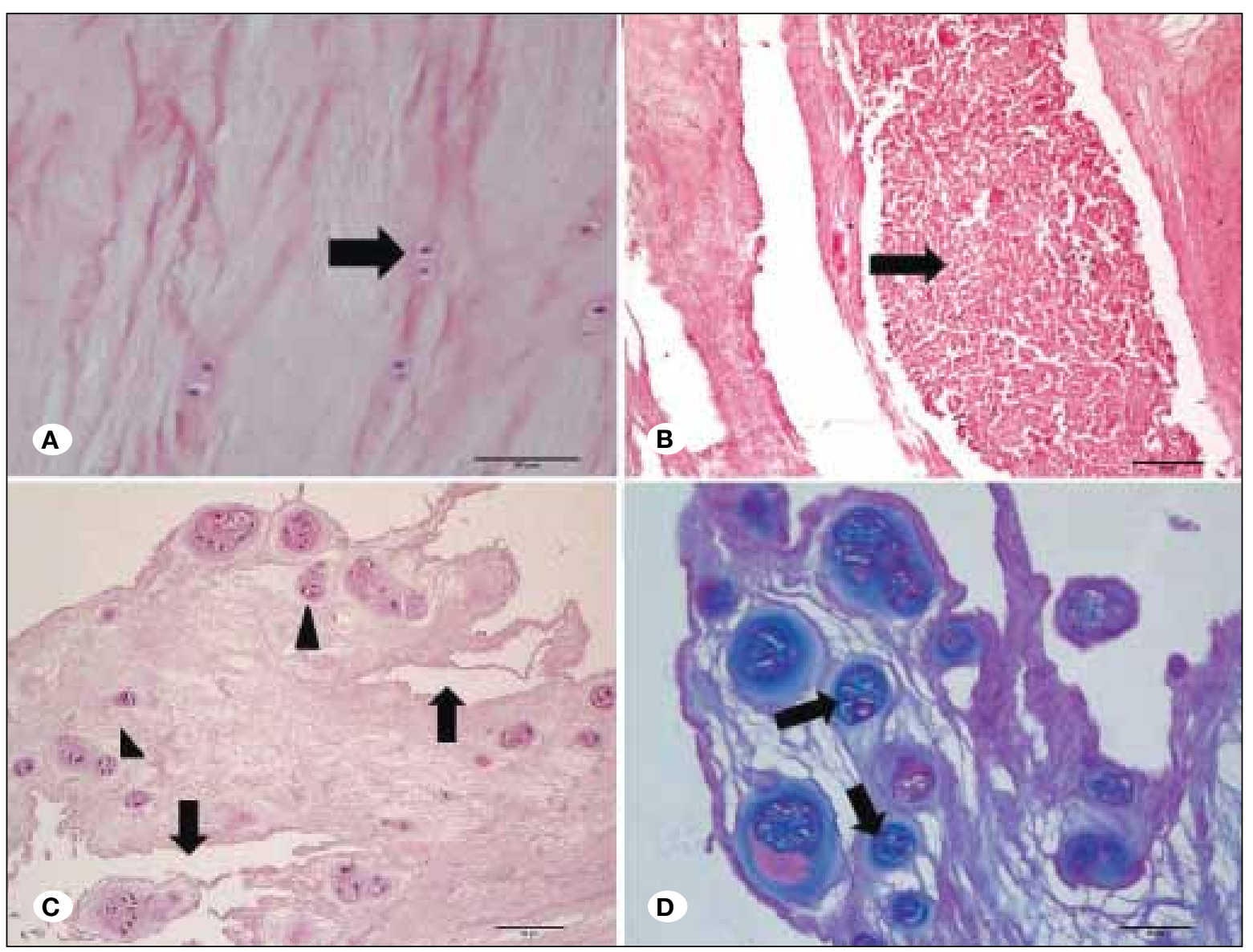

Figure 1:

A) Healthy intervertebral disc

B) Granular degeneration (arrow)

C) Increased cell density and huge clones (arrow head), and tears and clefts (arrow) D) Mucous degeneration areas stained in dark blue (arrow). A, B, C) HematoxylinEosin Staining D) Alcian BluePAS Staining (x10, scale bar $=50 \mu \mathrm{m})$. 


\section{Statistical Analyses}

For comparison of degeneration grades and genotypes of Fas, $B c l-2$ and Bax, Chi-square test was used. Numerical values obtained as a result of histological analyses (as mean \pm SD) were compared by using one-way ANOVA and Tukey's HSD tests. Relationship of expressional levels regarding Fas, $\mathrm{BCl}-2$ and $B a x$ with histological and radiological scores was evaluated with Independent t-test. The level of significance was determined to be $p \leq 0.05$.

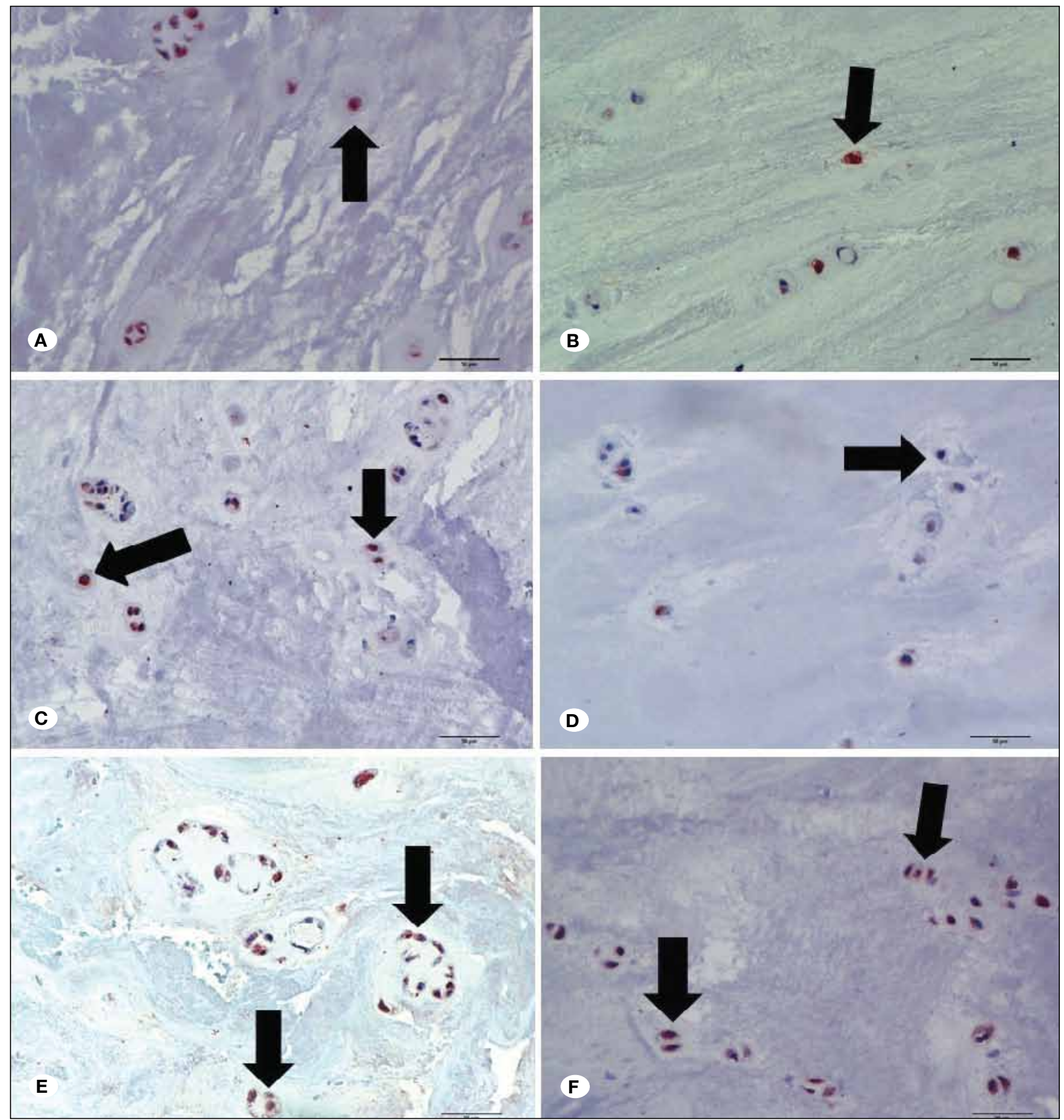

Figure 2: Immunopositivity was seen for Fas (A-B), Bcl-2 (C-D) and Bax (E-F) in degenerated disc cells (immunohistochemical staining with Fas, Bcl-2 and Bax primary antibodies, (x20, scale bar $=50 \mu \mathrm{m})$. 


\section{RESULTS}

For this study, 100 pieces of IVD tissues and 100 samples of peripheral blood collected from 100 patients with lumbar disc degeneration were used. The polymorphisms of Fas, $\mathrm{BCl}-2$ and Bax genes were assayed using DNA samples collected from all of the patients. Genotypes of these genes, immunohistochemical expressions of genes and radiological degeneration grades were compared with each other.

Distribution of genotypes of Fas, $\mathrm{Bcl}-2$ and Bax according to their disc degeneration grades were demonstrated in Table II. Of all patients; $2 \%$ had AA genotype, 19\% had AG genotype and $79 \%$ had GG genotype. AA genotype of Fas gene was not encountered in mild-type degeneration group. Frequency of genotypes of $\mathrm{BCl}-2$ gene was as follows, respectively: $\mathrm{AA}$ (34\%), AG (46\%) and GG (20\%). AA genotype of Bax gene was not encountered in any of the patients. Distribution of other genotypes of Bax gene was found to be as follows: AG $(18 \%)$ and $G G(82 \%)$. No relationship has been found among genotypes of $\mathrm{Fas}, \mathrm{BCl}-2$ and $\mathrm{Bax}$ and radiological degeneration grades ( $p=0.59 ; p=0.98 ; p=0.20$, respectively) (Table II). When distribution of genotypes of $\mathrm{Fas}, \mathrm{BCl}-2$ and $\mathrm{Bax}$ and ratio of positive cells were compared, a relationship was found only among GG genotype of $\mathrm{Bcl}-2$ gene and $\mathrm{Bcl}-2$-positive cells $(p=0.01)$. The ratio of $B c l-2$-positive cells detected in GG genotype of $B c l-2$ was more than those in $A A$ and $A G$ genotypes (Table III). Whereas no relationship was found among positive-cell ratio of both of $\mathrm{BCl}-2$ and degeneration grades ( $p=0.96$ and $p=0.72$, respectively), a relationship was found among Bax-positive cell ratio and degeneration grades $(p=0.05)$. In comparison of HDS and radiological degeneration grades, a difference was determined between mild and severe degeneration groups $(p \leq 0.001)$. Radiological and histological degeneration scores were compatible with each other (Table IV). It was determined that histological degeneration scores of patients who were evaluated as high-grade radiologically were also high.

\section{DISCUSSION}

IVDD is among commonly encountered causes of lumbar pain. In studies conducted in different populations, it has been reported that various genes may be related with this disease (11). Apoptosis is programmed cell death and it does not only participate in cell proliferation and differentiation, but also is responsible for pathogenesis of various diseases. Recent studies have suggested that apoptosis of disc cells leads to loss of IVD cells $(1,10)$, and extracellular matrix (ECM) degradation $(1,15)$.

Both death receptor pathway and mitochondrial pathway are simultaneously responsible for apoptosis in IVDD (24). Death receptor pathway is the most studied pathway related with apoptosis. Fas/FasL system plays an important role in this pathway. Expressions of Fas and FasL in normal and degenerated disc tissues were assayed in animal models. In rats in which IVD degeneration was induced, Fas expression was reported to be 8 -fold increased 3 weeks after annular laceration compared to normal IVD. Based on this result, it was suggested that Fas was effective in early disc degeneration (2). However, in our study, no difference has been observed among degeneration grades in terms of ratio of Fas-positive cells. We believe that this result is due to that majority of our patients were chronic cases who had complaint of lumbar pain for a long period of time.

In studies conducted in human herniated IVD tissue, Fas and FasL were reported to be expressed more in non-contained discs compared to contained discs $(15,24)$. Fas polymorphism $-1377 \mathrm{G}>\mathrm{A}$ ( $\mathrm{rs} 2234767$ ) is a substitution related with Sp1 binding site localized in FAS promoter. Sibley et al. (21) reported a significant relationship between the $-1377 \mathrm{G}$ allele and high level of gene transcription. Zhu et al. suggested that variations in Fas and FasL genes may induce apoptotic pathway by influ-

Table II: Comparison of Fas, Bcl-2 and Bax Genotypes and the Grades of Disc Degeneration

\begin{tabular}{|c|c|c|c|}
\hline Genotypes & $\begin{array}{c}\text { Grade } 2 \text { (mild) } \\
(n=33)\end{array}$ & $\begin{array}{l}\text { Grade } 3 \text { and } 4 \\
\text { (severe) }(n=67)\end{array}$ & $\begin{array}{c}\mathbf{p} \\
\text { values }\end{array}$ \\
\hline \multicolumn{4}{|l|}{ Fas } \\
\hline $\mathrm{AA}$ & 0 & 2 & \multirow{3}{*}{0.59} \\
\hline$A G$ & 6 & 13 & \\
\hline GG & 27 & 52 & \\
\hline \multicolumn{4}{|l|}{ Bcl-2 } \\
\hline$A A$ & 11 & 23 & \multirow{3}{*}{0.98} \\
\hline$A G$ & 15 & 31 & \\
\hline $\mathrm{GG}$ & 7 & 13 & \\
\hline \multicolumn{4}{|l|}{ Bax } \\
\hline$A G$ & 3 & 15 & \multirow{2}{*}{0.20} \\
\hline $\mathrm{GG}$ & 30 & 52 & \\
\hline
\end{tabular}

Table III: Comparison of Genotypes and Immunohistochemical Expressions of Fas, $\mathrm{Bcl}-2$ and Bax

\begin{tabular}{|c|c|c|c|}
\hline Genes & Genotypes & $\begin{array}{c}\% \text { Stained Cells } \\
\text { (mean } \pm \text { SD) }\end{array}$ & $\begin{array}{c}\mathbf{p} \\
\text { values }\end{array}$ \\
\hline \multirow{3}{*}{ Fas } & AA & $40.0 \pm 33.94$ & \multirow{3}{*}{0.79} \\
\hline & AG & $38.32 \pm 13.87$ & \\
\hline & $\mathrm{GG}$ & $40.75 \pm 13.21$ & \\
\hline \multirow{3}{*}{$\mathrm{Bcl}-2$} & AA & $16.03 \pm 8.57$ & \multirow{3}{*}{0.01} \\
\hline & $A G$ & $17.72 \pm 11.95$ & \\
\hline & GG & $25.25 \pm 12.77^{*}$ & \\
\hline \multirow{2}{*}{ Bax } & AG & $31.06 \pm 14.70$ & \multirow{2}{*}{0.21} \\
\hline & $\mathrm{GG}$ & $35.77 \pm 14.33$ & \\
\hline
\end{tabular}

${ }^{*} p \leq 0.05$, compared with $A A$ and $A G$ by using Tukey HSD test. SD: Standard Deviation. 
Eser B. et al: Apoptotic Gene Polymorphisms and Disc Degeneration

Table IV: Comparison of Disc Degeneration Grades, Histological Degeneration Scores and Immunohistochemical Expressions of Fas, $\mathrm{Bcl}-2$ and $\mathrm{Bax}$

\begin{tabular}{ccccc}
\hline & & \multicolumn{3}{c}{ \% Stained Cells (mean \pm SD) } \\
\hline Grade & HDS (mean \pm SD) & Fas & Bcl-2 & Bax \\
\hline 2 (mild) & $7.09 \pm 1.01$ & $40.36 \pm 12.86$ & $18.06 \pm 12.22$ & $38.91 \pm 16.43$ \\
\hline 3 and 4 (severe) & $10.39 \pm 1.78$ & $40.22 \pm 14.05$ & $18.94 \pm 11.21$ & $32.96 \pm 13.03$ \\
\hline $\mathrm{p}$ values & $\leq 0.001$ & 0.96 & 0.72 & 0.05 \\
\hline
\end{tabular}

HDS: Histological degeneration score, SD: Standard deviation.

encing expression of Fas and FasL and IVDD may develop as a result of that (27). Contrary to this thought, in previous studies, no relationship was found between especially Fas $-1377 \mathrm{G} / \mathrm{A}$ (rs2234767) polymorphism and lumbar disc pathologies. In both of two different studies conducted in the Chinese population, no relationship was reported between Fas $-1377 \mathrm{G} / \mathrm{A}$ polymorphism and lumbar disc herniation $(22,26)$. We also found no relationship between Fas gene polymorphism and IVDD. On the other hand, a different study conducted in the Turkish population reported that frequency of Fas-1377 GG genotype and $G$ allele was higher than the control group in patients with osteoarthritis of knee (19). In contrast, Yildir et al. (25) did not find any relationship between rheumatoid arthritis and the Fas $(-1377 \mathrm{G}>\mathrm{A})$ gene polymorphism.

The $B c /-2$ and Bax genes are involved in mitochondrial pathway of apoptosis. Bax gene causes mitochondrion rupture by leading to opening of voltage-dependent anion channels in mitochondrion. It has been suggested that $\mathrm{Bcl}-2$ protects normal IVD tissue from apoptosis (24). Bcl-2 binds to Bax and inhibits the pro-apoptotic function of Baxt. Alteration of the equilibrium between $\mathrm{Bcl}-2$ and Bax leads to formation of a pro-apoptotic signal $(8,17)$. Bax up-regulation and $B C l-2$ downregulation have been demonstrated in IVDD (24). Furthermore, in the same study, Bax expression was reported to be higher in non-contained discs than in contained discs. Single nucleotide polymorphisms in $\mathrm{BCl}-2$ gene have been detected in some diseases such as cancer and autoimmune diseases $(12,13)$. The A21G (rs1801018) variant is located in exon 2 of $B c /-2$ gene. Although the function of this variant remains unknown, it may be effective in transcription and translation of $B C l-2$. Only one study that reported the relationship between $\mathrm{BCl}-2$ gene polymorphism and disc degeneration has been encountered. In that study, a relationship between $\mathrm{Bcl}-2$ gene polymorphism and presence and severity of lumbar disc degeneration has been reported (20). In another study, a relationship among polymorphism of apoptotic Bax gene and its expression and cervical intraepithelial neoplasia was reported (7). However, in the same study, no relationship was found between polymorphism of anti-apoptotic $\mathrm{BCl}-2$ gene and the disease. Our study demonstrated that GG genotype of $\mathrm{Bcl}-2$ and ratios of $\mathrm{Bcl}-2$-positive cells were related with each other. Additionally, we determined a relationship also among ratios of Bax-positive cells IVD degeneration grades. Similarly to our results, Dagistan et al. (6) reported that in extrusion- and sequestration-type disc herniations, density of Bax-positive cells was more.

\section{CONCLUSION}

Our study is the first one to examine both polymorphisms and expressions of apoptotic genes together in patients with IVDD. Whereas no relationship was found among polymorphisms in Fas and Bax genes and their expressions, we determined a relationship between GG genotype of $\mathrm{Bcl}$ 2 and its expression. However, we believe that the samples from degeneration groups to be less influenced our results negatively. Therefore, we suggest that repetition of a similar assay with genes involved in apoptotic pathways in different ethnic societies will be beneficial.

\section{ACKNOWLEDGMENTS}

The authors would like to thank A. Said BODUR for helping with the statistical analysis. This study was funded by the research fund of Balikesir University.

\section{REFERENCES}

1. Ahsan R, Tajima N, Chosa E, Sugamata M, Sumida M, Hamada $\mathrm{M}$ : Biochemical and morphological changes in herniated human intervertebral disc. J Orthop Sci 6(6):510-518, 2001

2. Anderson DG, Izzo MW, Hall DJ, Vaccaro AR, Hilibrand A, Arnold W, Tuan RS, Albert TJ: Comparative gene expression profiling of normal and degenerative discs: Analysis of a rabbit annular laceration model. Spine 27(12):1291-1296, 2002

3. Antoniou J, Steffen T, Nelson F, Winterbottom N, Hollander AP, Poole RA, Aebi M, Alini M: The human lumbar intervertebral disc: Evidence for changes in the biosynthesis and denaturation of the extracellular matrix with growth, maturation, ageing, and degeneration. J Clin Invest 98(4):996-1003, 1996

4. Boos N, Weissbach S, Rohrbach H, Weiler C, Spratt KF, Nerlich AG: Classification of age-related changes in lumbar intervertebral discs: 2002 Volvo Award in basic science. Spine 27 (23):2631-2644, 2002

5. Buckwalter JA: Aging and degeneration of the human intervertebral disc. Spine 20 (11):1307-1314, 1995

6. Dagistan Y, Cukur S, Dagistan E, Gezici AR: Importance of IL-6, MMP-1, IGF-1, and BAX levels in lumbar herniated disks and posterior longitudinal ligament in patients with sciatic pain. World Neurosurg 84 (6):1739-1746, 2015 
7. Fernandes AT, Rocha NP, Vendrame E, Russomano F, Grinsztejn BJ, Friedman RK, Pinto AC, Klumb EM, Avvad E, Macedo J, Martinez-Maza O, Bonecini-Almeida Mda G: Polymorphism in apoptotic BAX $(-248 G>A)$ gene but not in anti-apoptotic BCL2 $(-938 \mathrm{C}>\mathrm{A})$ gene and its protein and mRNA expression are associated with cervical intraepithelial neoplasia. Apoptosis 20 (10):1347-1357, 2015

8. Ghribi O, Herman MM, DeWitt DA, Forbes MS, Savory J: Abeta(1-42) and aluminum induce stress in the endoplasmic reticulum in rabbit hippocampus, involving nuclear translocation of gadd 153 and NF-kappaB. Brain Res Mol Brain Res 96(1-2):30-38, 2001

9. Green DR, Kroemer G: The pathophysiology of mitochondrial cell death. Science 305 (5684):626-629, 2004

10. Gruber HE, Hanley EN Jr: Analysis of aging and degeneration of the human intervertebral disc. Comparison of surgical specimens with normal controls. Spine 23(7):751-757, 1998

11. Kalb S, Martirosyan NL, Kalani MY, Broc GG, Theodore $\mathrm{N}$ : Genetics of the degenerated intervertebral disc. World Neurosurg 77(3-4):491-501, 2012

12. Komaki S, Kohno M, Matsuura N, Shimadzu M, Adachi N, Hoshide R, Nishiyama S, Matsuda I: The polymorphic 43Thr bcl-2 protein confers relative resistance to autoimmunity: An analytical evaluation. Hum Genet 103(4):435-440, 1998

13. Loro LL, Johannessen AC, Vintermyr OK: Loss of BCL-2 in the progression of oral cancer is not attributable to mutations. $\mathrm{J}$ Clin Pathol 58(11):1157-1162, 2005

14. Luo X, Budihardjo I, Zou H, Slaughter C, Wang X: Bid, a Bcl2 interacting protein, mediates cytochrome $c$ release from mitochondria in response to activation of cell surface death receptors. Cell 94 (4):481-490, 1998

15. Park JB, Kim KW, Han CW, Chang H: Expression of Fas receptor on disc cells in herniated lumbar disc tissue. Spine 26(2):142-146, 2001

16. Park JB, Chang H, Kim KW: Expression of Fas ligand and apoptosis of disc cells in herniated lumbar disc tissue. Spine 26(6):618-621, 2001

17. Park JB, Lee JK, Park SJ, Kim KW, Riew KD: Mitochondrial involvement in fas-mediated apoptosis of human lumbar disc cells. J Bone Joint Surg Am 87(6):1338-1342, 2005
18. Schneiderman G, Flannigan B, Kingston S, Thomas J, Dillin WH, Watkins RG: Magnetic resonance imaging in the diagnosis of disc degeneration: Correlation with discography. Spine 12(3):276-281, 1987

19. Sezgin M, Barlas IO, Yildir S, Turkoz G, Ankarali HC, Sahin G, Erdal ME: Apoptosis-related Fas and FasL gene polymorphisms' associations with knee osteoarthritis. Rheumatol Int 33 (8):2039-2043, 2013

20. Shang XP, Sun XC, Wang YX, Ju BB: Association of BCL-2 polymorphism with the presence and severity of lumbar disc degeneration in the Chinese Han population. Clin Lab 58 (34):261-266, 2012

21. Sibley K, Rollinson S, Allan JM, Smith AG, Law GR, Roddam PL, Skibola CF, Smith MT, Morgan GJ: Functional FAS promoter polymorphisms are associated with increased risk of acute myeloid leukemia. Cancer Res 63(15):4327-4330, 2003

22. Sun Z, Ling M, Chang Y, Huo Y, Yang G, Ji Y, Li Y: Singlenucleotide gene polymorphisms involving cell death pathways: A study of Chinese patients with lumbar disc herniation. Connect Tissue Res 54(1):55-61, 2013

23. Tsujimoto $\mathrm{Y}$, Shimizu S: VDAC regulation by the $\mathrm{Bcl}-2$ family of proteins. Cell Death Differ 7(12):1174-1181, 2000

24. Wang $H$, Liu $H$, Zheng ZM, Zhang KB, Wang TP, Sribastav SS, Liu WS, Liu T: Role of death receptor, mitochondrial and endoplasmic reticulum pathways in different stages of degenerative human lumbar disc. Apoptosis 16(10):990-1003, 2011

25. Yildir S, Sezgin M, Barlas IO, Turkoz G, Ankarali HC, Sahin G, Erdal ME: Relation of the Fas and FasL gene polymorphisms with susceptibility to and severity of rheumatoid arthritis. Rheumatol Int 33(10):2637-2645, 2013

26. Zhang YG, Zhang F, Sun Z, Guo W, Liu J, Liu M, Guo $X$ : A controlled case study of the relationship between environmental risk factors and apoptotic gene polymorphism and lumbar disc herniation. Am J Pathol 182(1):56-63, 2013

27. Zhu GB, Jiang XR, Xia CL, Sun YJ, Zeng QS, Wu XM, Li XC: Association of FAS and FAS ligand polymorphisms with the susceptibility and severity of lumbar disc degeneration in Chinese Han population. Biomarkers 16(6):485-490, 2011 